\title{
Diachronně synchronní kontinuum-diskontinuum jako východisko, metoda i cíl Fukačovy hudební historiografie aneb definice není nikdy definitivní
}

\section{Diachronic Synchronous Continuum-Discontinuum as Jiří Fukač's Starting Point, Method and the Goal of Music Historiography or The Definition Is Never Final}

Stanislav Bohadlo / bohadlo@jmc.cz

Department of Music, Faculty of Education, University of Hradec Králové, CZ

\begin{abstract}
Jiři Fukač, representing the new Czech musicological generation as the young researcher (1959), lexicographer, reviewer (1961) and especially as the author of the textbook On studying musicology (1964, O studiu hudební vědy), refused Q. Adler's narrow separation of systematic and historic musicology. He systematically paved the way for "historizing" the traditional and modern musicology disciplines. His concept of music historiography was applied on sociology and aesthetics, on aspects of semiotics, terminology, thinking, stratification, hearing, reception, communication and education. So as he adopted the basic Josef Pekař's historiographical factors (1928, geographic location, neighboring cultures, the history of its own, a coincidence), so by his categories of paradigma, syntagma, diachronic synchronous continuum-discontinum and white spots left behind valuable methodology not only for music but also for the history of art disciplines and, naturally, even for the general history.
\end{abstract}

\section{Keywords}

Jiří Fukač, musicology, disciplines historizing, paradigma, syntagma, diachronic synchronous continuum-discontinum, white spots 
„Jako u jiných věd je pro dokonalého kapelnika nevyhnutelná znalost dějin hudby“

Johann Mattheson: Der vollkommene Capellmeister, Hamburg 1739

Jiří „Fukač byl prototypem “ nové muzikologické generace 2. poloviny 50. let, odvracející se od poválečných limitů marx-leninské ideologie, socialistického realismu, nacionalismu a anti-němectví, jak v roce 2005 postřehl jeho nejfrekventovanější spoluautor Ivan Poledňák. ${ }^{1}$ Zdůraznil 1) jeho „úctu k historickým faktům spjatým s uměním fakta interpretovat“ nebo také „postihnout historicitu jevü“, respektive ,jakéjsou kořeny daného jevu, vývoj, reflexe“, 2) jeho rané úsilí o „historiograficky založenou rekapitulaci vývoje celého oboru i jednotlivých jeho disciplin“a 3) „víceaspektovéneboli komplexnizkoumáníjevu různými muzikologickými disciplinami“.2 Jak známo, Jiří Fukač zahájil svou muzikologickou dráhu základním výzkumem významného pramenného souboru Křrižovnický hudebni inventář (1959), ale zároveň už spolupůsobil při vzniku Československého hudebniho slovniku osob a institucí, tedy specifického hudebně historického výstupu. Úvod do studia hudebni vědy Jana Racka z roku 1949 byl přitom pro studenty hudební vědy generace Jiřriho Fukače jedinou českou příručkou oborové systematiky.

Ještě jako redaktor univerzitního časopisu kriticky hodnotil v Hudebni vědě (1961) první svazek Knižnice Hudebnich rozhledů, zejména diskusně a recenzně zaměřené příspěvky, a naopak vyžadoval v obsahu publikace scházející 1) bibliografii zaměřenou na zahraniční produkci: „Vždyt’ je zapotřebi zaujmout vztah $i k$ základnim dílưm nejčerstvějši zahranični literatury“, 2) zahrnutí hudebněhistorického výzkumu, a 3) nejen pražská témata. „Lze očekávat, že časem se zvětši jeho rozsah, obsahové členěni nabude určité formálni dokonalosti u vědeckého sborniku nezbytné."3

Základní muzikologické teze systematicky zformuloval už v roce $1964 \mathrm{v}$ podobě „červených“ skript pro studenty hudební vědy, z kterých čerpala naše i další generace. Vedle metody experimentálního zkoumání hudebních jevů a analytické metody, akcentuje právě metodu historicko-srovnávací, která „zejména v historických disciplínách zahrnuje metody kritického dějepisectví, metodu filologicko-historického studia pramenů, důsledné kritické srovnáváni př́buzných projevů a jejich klasifikaci."4 Adlerovu dělení na historickou a systematickou muzikologii také prozíravě vytýkal „poněkud schematické odděleni historických problémů od problémů systematických. I když mezi systematickou a historickou interpretaci určité otázky je značný rozdíl, přece jen nelze oba postupy oddělit." Dokládá to přesvědčivě např. tím, že každá „systematická“ hudební teorie je jen jedním snímkem na historické ose hudebně teoretických názorů. V kapitole III. Prameny a literatura klade důraz na heuristiku, práci s prameny, evidenci a katalogizaci pramenů, pramennou dokumentaci a edici pramenů, práci s literaturou a bibliografii.

1 POLEDŇÁK, Ivan. Dvě kapitoly o Jiřím Fukačovi. SPFFBU H 38-40, Brno, 2006, s. 33-46.

2 Tamtéž, s. 34.

3 FUKAČ, Jiří. Knižnice Hudebních rozhledů, řada B, sv. 1. řídí J. Jiránek a B. Karásek s redakční radou. Praha 1961, 153 stran. Hudebni věda, 1961.

$4 \quad$ FUKAČ, Jiří. O studiu hudebni vědy. Praha, 1964, s. 8. 
Jako zakladatel a první šéfredaktor měsíčníku Opus musicum (1969-1970) mohl už tato kritéria prakticky aplikovat. Prostor pro dílčí hudebně historické studie následovala hudebně historická praxe a vědecká témata v oblasti lexikografie, sémiotiky, stratifikace a taxonomie, pedagogiky, estetiky a médií. Pro podporu historiografického zaměření a propojení oborů inspirativně přispíval i jeho zásadní podíl na mezinárodních brněnských kolokviích, která navázala spojení s evropskou muzikologií a relativizovala režimní nesmiřitelnost „socialistické“ a „kapitalistické“ muzikologie.

Nejenom že významně zasáhl do reflexe československé hudební vědy svými názory a formulacemi v trojsvazkové publikaci Hudebni věda (1988), ${ }^{5}$ ale vytyčil i zásadní historiografické otázky do budoucnosti:

1. Vztah evropské a české hudby (teze o domácí simplifikaci), chybí širší kontext pro postižení domácí specifičnosti a argumentoval tématy úspěšných kolokviî́ (Musica bohemica et europea 1970, Svazky, vztahy, paralely 1973, Česká hudba svètu, svèt české hudbě 1974).

2. Specifičnost české hudby, národnosti, českosti, reakce na německý nacionální výklad - po 1945 s opačným znaménkem, proklamativně, lidová píseň - „scházi plošné analýzy“.

3. Otázky vztahu slova a hudby v různých epochách, periodizace, otázky stylových znaků jednotlivých období v posledních třiceti letech neřešeny.

Díky „brněnským kolokviím a mezinárodní konfrontaci výrazněji vynikla bílá místa, opomíjené aspekty i rozdíly v metodách mezi historiografy ze socialistických zemí a z ostatní ciziny. “6 Jiří Fukač zde rekapituluje stav historiograficky zaměřených nebo historiograficky relevantních sborníků, časopisů a zájmových publikací, bibliografické soupisy, Souborný hudební katalog - RISM. Upozorňuje i na popularizační články - jubilea, i když nezmiňuje regionální produkci (fakultní, muzejní, archivní, výroční sborníky). Na této kolektivní publikaci se podle vlastních slov podílel bezmála třetinou všech textů. ${ }^{7}$

V práci Mýtus a skutečnost hudby (1989) se sice formou popularizačního traktátu zabývá definicí pojmu a fenoménu hudba, ale zároveň tím synteticky stanovuje základní východiska, principy, vazby na jiné dílčí vědní obory a kritéria hudební historiografie. Opírá se přitom o často citovaný výrok Hanse Heinricha Eggebrechta, že nejpřesnější definicí (hudebního) jevu je jeho historie. Argumentuje nutnost kombinovat mnoho muzikologických oborů a disciplín, respektive historického a systematického. Tradiční muzikologická systematika $\mathrm{z}$ podstaty věci definovala vedle dějin hudby jednotlivé hudebně vědné obory nebo disciplíny a jejich metodologie a pojmoslovný systém. Zpravidla v daném „okamžiku“. Každá taková definice a výklad apriorně strádaly právě svou okamžitou synchronicitou (byt na nejaktuálnější úrovni rozvoje oboru), zatímco historické obory dávno pochopily, že diachronní - chronologické uvažování není pouhým sledem př́čcin a následků ve výkladu určitého jevu, ale že s sebou „vleče“ i proměny termínů,

5 LÉBL, Vladimír - POLEDŇÁK, Ivan (red.). Hudebni věda I-III. Historie a teorie oboru, jeho světový a český vývoj. Praha, 1988, 1036 s.

6 Hudebni věda III., s. 756.

7 „Etwa 350 S. von mir geschrieben.“ BOHADLO, Stanislav (ed.). Jiř́ Fukač Festschrift / Commemorative Book. Hradec Králové / Náchod, Gaudeamus, 1998. ISBN 80-7041-125-2 a GATE ISBN 80-901712-5-7, s. 7. 
pojmů a definic. Teprve, jak říkáme, historická analýza a historický výklad těchto termínů a pojmů jsou mnohem přesnější definicí. Jak je však zřejmé, definice, ač o to usiluje, není a nemůže být nikdy definitivní. Připomeňme jen, jaké rozdílné významy měly termíny loutna, harmonia, lyra, ligatura, chanson, madrigal, canzona, fuga, notace, corno, toccata, aria, sinfonia, hudební divadlo, taice ${ }^{8}$ atd. Vědomě tu z historiografického úhlu pohledu upozorňuji také na Fukačovy práce o hudební sémiotice. Ta je přece v podobě synchronních dobových termínů a zejména notace od historikovy práce neoddělitelná. Platí to i o výkladech historických hudebních termínů ve slovářích a jazykových slovnících (viz M. Štědroň a D. Šlosar) nebo o organologii.

Monumentální „věcný“ Slovník české hudební kultury (1997) je mj. koncepčně pojatý jako historiografická rekapitulace základních jevů českého přínosu hudbě a hudební kultuře ${ }^{9}$ Heslo Hudební historiografie (spoluautor M. K. Černý) požaduje příslovečné „zhistoričtění“ muzikologických disciplín nebo oborů a křížení historiografie se systematikou, i když řešení mohou být vícevrstevnatá, složitá a dokonce nepřehledná. To však Fukač nepovažuje za nedostatek! Jde o jiné úhly pohledu proti zjednodušení a zkreslení.

Tradiční západní muzikologie vždy úzce definovala metodologie: Historickou metodou rozuměla empiricko-pozitivistickou interpretaci pramenů + filozoficko-teoretický výklad, tj. změny a kauzalita, periodizace, biografie, formy, styly, význam z hlediska historického, estetického a sociologického kontextu. ${ }^{10}$

Fukač metodologie spojoval, kombinoval, obohacoval a prolínal. Směřoval ke globální historiografii s výhledem do budoucnosti - předpovědi - na bázi diachronně synchronního kontinua-diskontinua. Za epochální objev považoval historičnost kategorií hudebního myšlení a hudebního slyšení v návaznosti na Scheringa a Besselera. Od biografického popisu ke genetické a stylové analýze skladatelova díla, kulturním determinantům, edicím korespondence, zájmu o „menší skladatele“ v regionalistice aj. Projevilo

8 Ř́jnová konference v Neapoli Il mondo di Gennaro Magri. Danza, musica e opera nell'Europa dei Lumi (6.-8. 10. 2016) se mj. zabývala tím, co se ve verbálních pramenech o tanci 2. poloviny 18. století v Itálii, Španělsku a Francii označovalo jako taice. Specialisté na rekonstrukce tanečních kroků marně hledali popis tohoto tance, aby ho mohli začít rekonstruovat. Nakonec to nebylo možné bez hudebně heuristického úsilí. Objevily se nedávno sborníky tanečních skladeb s označením taice, z nichž vyplývá, že to není konkrétní hudebně-taneční forma daná metrem a charakteristickými kroky, nýbrž je to prosté terminologické zkomolení a zápis výrazu deutche, teutche, taice. Tedy typ kontratance. Tito badatelé zároveň rozpracovávají - později než muzikologie - speciální sémiotiku, resp. jak převést popis s danou hudbou do pohybu.

9 POLEDŇÁK, s. 35.

10 Po historiograficky zakladatelském díle J. N. Forkela, F.-J. Fétise a G. Nottenbohma přichází až Quido Adler s kodifikací historické a systematické oblasti muzikologie v díle Umfang, Methode und Ziel der Musikwissenschaft (1885). Quido Adler, ačkoliv chápal hudbu jako sociální fakt, nevěnoval například speciální pozornost hudebním institucím. Carl Dahlhaus definoval (vycházeje z francouzského strukturalismu) hudebně-historickou metodu jako „dlouhodobý sled složitých a navzájem reagujicích vrstev, jehož prvky zachycuje historik v momentálním pozastaveni tohoto proudu“ (odmítl tím narativní dějepis a biografie) a (v návaznosti na Frankfurtskou školu) zavedl obrazy „konstelace“ a „silového pole“ - každé (hudebně) historické téma představuje komplexní vzorec konstitutivních částí, které jsou v dynamickém stavu přitažlivosti a odpudivosti navzájem. V analýze sledoval „sedimentované dějiny“ (nikoliv skryté hudební vazby) s historickými závěry. I přes variabilitu svých metod zůstával fascinován mystériem uměleckého zážitku a mistrovským dílem v kulturním kontextu. Americká muzikologie 80 . let byla zaměřena v duchu New Criticismu na pozitivistické ocenění hudebního textu zásadních děl, jeho pramenů, geneze a génia (později rozšířeno na žánry a styly). 
se to opět nejen v Úvodu do studia hudební vědy $(1995,2005)^{11}$, ale i prakticky při spolupráci na Lexikonu zur deutschen Musik-Kultur (2000). ${ }^{12}$

Český hudební slovník osob a institucí (od 2001) ještě pod vedením Jiřího Fukače začal v Pravidlech pro autory promítat historismus do některých nových kategorií (populární hudba, folklór, hudební divadlo, popularizace hudby, hudební průmysl, agentury) a hudebně historický základ mají i základní podkapitoly každého hesla: Biografie, Dílo, Recepce, Seznam díla, Literatura s ev. periodizací a chronologií. Z rozsahových důvodů se u osobností, které se v českých zemích „jen narodily“, heslo orientuje na pobyt „doma“ a jen na bohemikální aspekty v zahraničí. „Heslo pak v žádném případě neusiluje o úplnost v postižení života a díla." (Aktualizace Petra Macka, Petra CH. Kaliny a Simony Sedláčkové z roku 2010 ${ }^{13}$ ). Otázky metodologie Pokyny nespecifikují, jedná se o technickou metodiku.

Historiografie hudby tvořila i neoddělitelnou součást Fukačových úvah o hudební pedagogice, jak to v roce 2006 shrnuli v předmluvě k Fukačovu sborníku P. Macek a I. Poledňák: „Tak jako jeho práce reflektovala komplexní rozmanitost hudby samé, tak on sám podtrhával a analyzoval edukativní rozměr: že hudba byla a je součástí antropogeneze a její esencí je předávání hudby od generace ke generaci." 14

Je patrné, že Jiří Fukač se bytostně neztotožnil s americkým pojetím muzikologie a historiografie (vzpomínám na určitou lítost Michaela Beckermana v seminářích o české hudbě na University of California v Santa Barbara, 1999) a vycházel z německé muzikologické školy. Jeho pojetí hudební historiografie zpětně rozšířilo tuto disciplínu nejen o pohledy sociologické a estetické, ale i o aspekty sémiotiky, pojmosloví, myšlení, stratifikace, slyšení, recepce, komunikace a pedagogiky. Tak jako adoptoval základní historiografické faktory Josefa Pekaře z roku 1928 (geografická poloha, sousední kultury, dějiny samy, náhoda), aniž by to kdy explicitně uváděl, tak svými kategoriemi paradigmat, syntagmat, diachronně synchronního kontinua-diskontinua a bílých míst zanechal cennou metodologii nejen pro hudební historii, ale i pro uměnovědné obory a přirozeně i pro obecnou historii.

\section{Bibliography}

BOHADLO, Stanislav (ed.). Jiřri Fukač Festschrift / Commemorative Book. Hradec Králové / Náchod, Gaudeamus, 1998. ISBN 80-7041-125-2 a GATE ISBN 80-901712-5-7.

11 POLEDŇÁK, Ivan - FUKAČ, Jiř́i. Úvod do studia hudebni vědy, Olomouc, 1995, 2005.

12 HADER, Widmar (Projektleiter). Lexikon zur deutschen Musik-Kultur. Böhmen, Mähren, Sudetenschlesien. SMI München, 2000. ISBN 3-7844-2799-5.

13 MACEK, Petr - KALINA, Petr CH. - SEDLÁČKOVÁ, Simona. Český hudební slovník osob a institucí. Pravidla pro autory - seznam zkratek - aktualizovaný stav 2010 (certifikovaná metodika). Musicologica Brunensia 2010, 45, 1-2, s. 283-297.

14 MACEK, Petr - POLEDŇÁK, Ivan. In Memoriam on the Seventieth Birthday of Jiř́ Fukač. Sbornik praci Filozofické fakulty brnènské univerzity, Studia minora facultatis philosophicae universitatis Brunensis H 38-40, Brno, 2003-2005, s. 12. 
FUKAČ, Jiří. Knižnice Hudebních rozhledů, řada B, sv. 1. řídí J. Jiránek a B. Karásek s redakční radou. Praha 1961, 153 stran. Hudební věda, 1961.

FUKAČ, Jiř́i. O studiu hudební vědy. Praha, 1964.

HADER, Widmar (Projektleiter). Lexikon zur deutschen Musik-Kultur. Böhmen, Mähren, Sudetenschlesien. SMI München, 2000. ISBN 3-7844-2799-5.

LÉBL, Vladimír - POLEDŇÁK, Ivan (red.). Hudební věda I -III. Historie a teorie oboru, jeho světový a český vývoj. Praha, 1988, 1036 s.

MACEK, Petr - KALINA, Petr CH. - SEDLÁČKOVÁ, Simona. Český hudební slovník osob a institucí. Pravidla pro autory - seznam zkratek - aktualizovaný stav 2010 (certifikovaná metodika). Musicologica Brunensia 2010, 45, 1-2, s. 283-297.

MACEK, Petr - POLEDŇÁK, Ivan. In Memoriam on the Seventieth Birthday of Jiřri Fukač. Sborník prací Filozofické fakulty brněnské univerzity, Studia minora facultatis philosophicae universitatis Brunensis H 38-40, Brno, 2003-2005.

POLEDŇÁK, Ivan - FUKAČ, Jiří. Úvod do studia hudební vědy, Olomouc. 1995, 2005.

POLEDŇÁK, Ivan. Dvě kapitoly o Jiřím Fukačovi. SPFFBU H 38-40, Brno, 2006. 